\title{
CONSIDERAÇÕES A RESPEITO DOS CULTOS PRIMITIVOS E A FUNÇÃO DO SAGRADO ${ }^{1}$ (1913)
}

\author{
Émile Durkheim
}

A comunicação do Sr. Laberthonnière chegou até mim somente depois da reunião, de modo que não pude levá-la em conta nem na minha exposição nem no decorrer da discussão. Eu vou, portanto, tentar respondê-la sumariamente.

Manifestamente, toda a argumentação do Sr. Laberthonière tende a demonstrar que as religiōes primitivas não são religiões propriamente ditas. Entre os cultos ditos inferiores e aqueles dos povos ditos civilizados, ele pretende traçar uma linha divisória clara. Vejamos no que ela consiste.

Segundo ele, os ritos dos primitivos visariam unicamente a obter bens de ordem material e as crenças correspondentes teriam por objeto os deuses e as forças que se movem no plano dos fenômenos. Tudo o que o australiano demanda de seu culto é que os animais cresçam, que as plantas se desenvolvam, que a alimentação seja abundante etc. É sua existência física e fenomênica que ele tem em vista. Ao contrário, o crente das religiôes verdadeiras tende a se desfazer de seu ser físico; ele tem o dever de renunciá-lo para viver uma vida superior. Entre essas duas atitudes do pensamento e da vontade, haveria, portanto, uma verdadeira oposição.

$\mathrm{Na}$ verdade, eu não me fiz entender bem; porque, se há uma ideia a qual eu retorno a cada página do meu livro é a de que a verdadeira razão de ser dos ritos primitivos não está nos serviços psíquicos que o fiel geralmente espera deles, mas nas finalidades morais que têm por objetivo atingir. Sem dúvida, quando o australiano quer explicar para si mesmo suas práticas tradicionais, ele diz que elas servem para fazer crescer sua barba, para the conferir a virilidade,

\footnotetext{
${ }^{1}$ Extraído do Bulletin de la Société Française de Philosophie, 13. Carta endereçada à Société, após a exposição feita por Durkheim sobre a obra As Formas Elementares da Vida Religiosa [cujo conteúdo consiste no artigo precedente].
} 
para lhe dar saúde etc.; mas, se esse conformismo religioso não tivesse outra origem, ele não poderia se manter, já que todos esses efeitos materiais são imaginários e que o primitivo, cedo ou tarde, perceberia o erro custoso que cometera. Na realidade, se ele está ligado a essas cerimônias, é porque elas são necessárias para criar e recriar periodicamente o ideal moral que faz a unidade do grupo e do qual os indivíduos são os servidores. Elas servem, portanto, a fins que extrapolam os interesses sensíveis e individuais, tal como aquelas que o cristão pode celebrar atualmente. Toda a diferença reside na maneira como um e outro dá-se conta de sua fé: o cristão tem uma consciência mais clara da regra puramente moral da religião; o primitivo tem um sentimento mais obscuro em relação a ela. Mas o estado no qual os dois se encontram quando vivem da vida religiosa não difere em natureza. Um e outro, saibam eles ou não, entregam-se a fins superiores que ultrapassam infinitamente o círculo de preocupações utilitárias. Quando vemos no primitivo uma espécie de materialista constitucional, somos enganados por aparências puramente exteriores: assumimos o modo como o crente justifica seu estado, pelo estado em si; confundimos a explicação que um espírito inculto pode dar de uma realidade complexa com a realidade em si. É conveniente ainda acrescentar que, às vezes, o australiano mesmo não atribui qualquer finalidade física a seus ritos: é notadamente o caso de importantes cerimônias que estudei em meu livro.

Inversamente, aliás, seria fácil demonstrar que não há religião, mesmo entre os mais elevados e os mais idealistas, de onde todo fim físico e materialista esteja excluído. Não há culto em que ritos não sejam celebrados para conjurar a doença, para assegurar aos fiéis sucesso na vida, para prevenir acidentes etc. O Sr. Labethonnière responderá que, segundo ele, essas são sobrevivências supersticiosas das quais a verdadeira religião deve se libertar. Mas eu me propus a estudar a religião tal como ela é e tal como ela tem sido realmente praticada pelos homens, e não a concepção ideal que pode ser feita por tal ou tal pessoa.

Aliás, se, entre esses diferentes estados religiosos, eu visse somente diferenças de graus, estaria longe de ignorar sua importância. Notadamente, o fato de que o cristão, por exemplo, tem um sentimento mais nítido daquilo que constitui a verdadeira função da religião, está longe de me parecer

Debates do NER, Porto Alegre, ANo I3, N. 22 P. 63-66, JUl./DeZ. 2012 
insignificante. Uma mais alta consciência dos fins aos quais serve a religião permite melhor entendê-los, mas não muda radicalmente a natureza.

De uma maneira geral, como se pode dizer que as crenças e as práticas dos primitivos se movem no plano do fenomênico? Eu, ao contrário, mostrei que todas as religióes, mesmo as mais humildes, somam ao plano do dado um plano de existência inteiramente diferente, que se sobrepõe ao primeiro e que é inteiramente criado pelo pensamento: o plano do sagrado.

A segunda objeção que me endereça o Sr. Laberthonnière parece repousar sobre uma confusão do mesmo gênero.

Segundo o Sr. Laberthonnière, é necessário distinguir entre viver pela sociedade e viver para a sociedade, e meu erro seria não ter feito essa distinção. $\mathrm{O}$ homem vive pela sociedade no sentido de que ela contribui para fazer dele aquilo que ele é: mas então ele se submete a ela sem a querer. Viver para a sociedade é verdadeiramente querê-la, não simplesmente tal como ela é, mas tal como ela deveria ser. Viver para a sociedade é um ato moral, religioso, pelo qual o indivíduo se eleva acima de sua natureza animal. Quando se limita a viver pela sociedade, somente aceita passivamente um estado acabado.

Receio que essa distinção seja um pouco escolástica e que entre esses dois estados haja, no máximo, diferenças de graus. Uma vez que a sociedade é, como admite Sr. Laberthonnière, uma parte essencial do homem, esse não pode não querê-la, na medida em que quer a si mesmo. Caso contrário, ele se colocaria em contradição com sua própria natureza. Desse simples ponto de vista, negar a sociedade é, para o indivíduo, negar a si mesmo. Sem dúvida, pode-se fazê-lo, acontece a todo o momento que o homem se doe ao grupo sem saber por quê, com uma espontaneidade cega, porque é conduzido a isso por todo seu ser. Mas, de início, há excesso de palavras para qualificar o sofrimento e a passividade dessa doação espontânea de si. O Sr. Laberthonnière parece falar em termos bem desdenhosos dos grandes movimentos de entusiasmo coletivo. Eles não são desprezíveis; não devemos a eles todos os grandes ideais coletivos vividos pela humanidade? Eles não implicam qualquer constrangimento, mas, ao contrário, são feitos de momentos felizes. Já que, nesses movimentos de efervescência, os indivíduos estão fora de si. O Sr. Laberthonière, muito justamente, fez notar que eles parecem intoxicados. Não 
há nada nessa comparação cuja natureza rebaixe o estado no qual eles se encontram. O Sr. Laberthonière não ignora que não haja religião, seja no presente ou no passado, que não tenha recorrido a procedimentos físicos para colocar os fiéis no estado religioso que queriam suscitar: fizeram-lhes beber líquidos excitantes, intoxicaram-lhes, fizeram-lhes queimar perfumes, embriagaramlhes de cantos e música, ou ainda, ao contrário, provocaram-lhes, por meio de jejuns repetidos ou prolongados, espécies de delírios. A objeção que o Sr. Laberthonière me endereça poderia, então, voltar-se contra as próprias religiōes, tais como elas são ou como foram: ora, essa objeção não tem maior valor contra essas religiôes do que contra a maneira como eu as explico. Eu mostrei no meu livro que todos os grandes estados religiosos são, por condição, estados físicos que, tomados por si sós, são propriamente patológicos ou parentes próximos de estados patológicos. Mas não há nesse parentesco nada que seja humilhante para a religião. É somente a prova, como eu disse, de que a vida religiosa, assim como toda vida social, quando é muito intensa, violenta nossa natureza animal, perturbando seu funcionamento normal.

Inversamente, não vejo como pode-se viver para a sociedade se não se vive por meio dela. Se a sociedade não ocupasse todo nosso ser, não teríamos razão para querê-la conscientemente. É somente tomando consciência de nossa natureza social que podemos nos doar deliberadamente e voluntariamente à sociedade. E, sem dúvida, essa consciência não é uma coisa de pouca importância: no entanto, ela não cria o estado que ela ilumina, o qual, aliás, jamais é plenamente inconsciente. Onde, então, há diferença de natureza? Por que, em um caso, estamos ligados à sociedade que é, e, no outro, a uma sociedade ideal? Eu fiz ver que em todos os casos, o que queremos é a alma da sociedade, e essa alma é feita de grandes ideais nos quais a sociedade representa a si própria, não como ela é, mas como ela aspira a ser. É também o que explica que, desejando a sociedade, podemos, em algum sentido, revoltar-nos contra ela: é que conflitos são frequentes entre ideais diversos que dividem a alma coletiva. Os de ontem não estão de acordo com os que se encontram em via de formação ou de realização.

\section{Tradução de Fernanda Heberle Revisão técnica Raquel Weiss}

